\title{
Peculiarities of affects at personal psychic development
}

\section{A. D. Tereshchuk}

\author{
Kostiuk Institute of Psychology of the NAPS of Ukraine, Kyiv, Ukraine \\ Correspondingautor. E-mail: tereschuk2011@meta.ua
}

Paper received 05.12.17; Revised 08.12.17; Accepted for publication 10.12.17.

https://doi.org/10.31174/SEND-HS2017-146V24-09

\begin{abstract}
The article is devoted to the study of changes in affects in the course of a person's psychological development. Such changes cannot be reduced to the formation of the mechanisms of defense against strong and unpleasant affects. It is proved that in the course of psychological development, affects have their own trajectory, while the formation of defensive mechanisms is associated, to a large extent, with the defects of this development, because all psychological events, thoughts, and memories have their own affective tint. Each affect has its own history and is associated with some kind of problems in the life of each individual. Some techniques for improving the psychological and emotional state are presented, which contributes to the development of a person's adaptive resources, his/her psychological resistance to a traumatic experience, and his/her resistibility in difficult life situations, as well as for the development of humanely oriented behavior patterns.
\end{abstract}

Keywords: affects, affective reactions, emotions, behaviors, psychological development, activity.

Introduction. For the person to behave normally, it is necessary to ensure the implementation of planned actions in realtime and real-world conditions. The role of emotions is extremely important in this process since it is emotions that are one of the main mechanisms for regulating the activity of all living beings. The emotions themselves are the activity; they are the driving force for all organic beings, which is naturally developed and operating from within. In an attempt to obtain a systematic view of emotions, it is useful to take into account that each psychological event has an affective component. Because all psychological events, thoughts, and memories have their own affective tint. Each affect has its own history and is associated with some kind of problems in the life of each individual.

The analysis of research and publications has shown that in modern psychology, there are two different understandings of the nature and essence of affects: the first is the understanding of affects, affective reactions, as reactions of a special type, and the second one is the understanding of affects as a certain quality that characterizes the body reactions under certain conditions. The second point of view stems directly from Spinoza's doctrine of affects. Spinoza's doctrine of affects establishes very important psychological mechanisms and laws and anticipates a number of points put forward by modern psychology. He considered affects to be the main driving force behind the behavior, and first of all considered the drives associated with the body and with the soul to be among them. Later, S. Freud equated affects to psychic energy as a source of motivation. A. R. Luria who ran the Laboratory for the Study of Affective Reactions, along with A. N. Leontiev proved the existence of affective and trace processes in their collaborative studies, as well as individual differences in affective responses. The affects exist both in the body and in the psyche. After all, affective processes depend on how the things that cause them are refracted in the person's head, i.e. on the system of values that form the consciousness [6, C.22].

The purpose of the article is to present the current problems of studying the changes in affects in the course of the personal psychological development.

The exposition of the basic material. Affect is nothing other than a strongly expressed emotion. According to G. A. Fortunatov [7], emotion is a psychological excitement, whereas affect is a storm. Any emotion can reach the level of affect if it is caused by a strong or especially meaningful for the person stimulus. Affect as a kind of emotion is characterized by:
1) rapid occurrence;

2) very high intensity of experience;

3) short duration;

4) rapid manifestation (expression);

5) unaccountableness, i.e. a decrease in the conscious control over one's actions; in a state of affect, a person is not able to control himself/herself. In a state of affect, little thought is being given to the consequences of what is being done, so that the behavior of a person becomes impulsive. Such a person is said to be unconscious;

6) diffuseness; strong affects capture the entire personality, which is accompanied by a decrease in the ability to switch attention, narrowing the field of perception, the attention control focuses mainly on the object that caused the affect ("anger clouds the eyes," "rage blinds") [3, C.54].

Freud and his followers considered only the negative emotions that arise as a result of conflicting drives. Therefore, they distinguish three aspects of affect: the energy component of the instinctive drive (the "charge" of affect), the process of "discharge," and the perception of the final discharge (sensation, or emotion experience). But the Freudian understanding of the mechanisms of the emergence of emotions as unconscious instinctual drives was criticized by many scientists [8].

A frequent manifestation of affect under normal conditions is indicative either of the person's bad manners (the person allows himself/herself to enter into an affective state) or of his/her neuropsychological illness. However, such an understanding of affect is inconsistent with the use of the term "affect" to denote any emotional reactions, which is characteristic of Western psychology. For example, the fourth part of the book by Ph. Tyson and R. Tyson (1998) is called "Affect" rather than "Emotions;" following A. Compton and P. Knapp [9], affect is determined by the authors as a mental structure that includes motivational, somatic, expressive, communicative, emotional, or sensory components, as well as an associated idea or a cognitive component. They reserve the terms "feeling" and "emotion" for the experienced and behavioral aspects of affects, respectively [3, c. 54].

Henry Krystal singled out the following components and aspects of affect: cognitive, hedonic, "expressive," and activating. He did not argue that the cognitive aspect was always present, but in clinical situations, it is useful to look for the meaning implied in the affect, as well as the "history behind it." The hedonic element of affects is related to the fact that they have a quality of pleasure or suffering that gives them a 
motivational role. A blocked instinctive drive is directly discharged through the physiological component of affect (the so-called expressive element); so, deterioration in fantasy output is observed.

These three components of affect - cognitive, physiological, and hedonic - represent the totality of information or signal contents of affect. But only if these three affect components occur simultaneously and are free from blocks that cause isolation or dissociation (or other "defenses" from affects), and only if the person is capable of adequate "reflexive self-awareness" [10;11]. In addition to these three components, which are a signal and autonomous information, there is a fourth aspect of emotions that goes beyond the simple signal function. It is the activating aspect of the emotion. In fact, affects influence the state of excitation and most of the bodily functions [2].

To prove the existence of such a phenomenon as a state of affect, several characteristic features were singled out:

- short duration and transiency of affective reactions;

- suddenness and unexpectedness of the action in a certain situation;

- perception of what is happening in parts (fragments) with the predominance of more important experiences;

- loss of self-control over the actions (aimlessly repeated movements, direct actions);

- the affect itself being a strong emotional discharge, which can be accompanied by uncontrollable actions;

- state of apathy and physical weakness after the affect is over [4].

Each affect has its own history and is associated with some kind of problems in the life of a particular individual. For example, an emotion that was overwhelming in the past is subsequently perceived as dangerous. When there is a threat that the affects can become intolerable or insurmountable, it is useful to have different strategies and techniques that reduce distress and allow you to later return to the full conscious experience of your own painful experience. Among the widely used means of self-help are short-term states of altered consciousness, attention switch, trauma ignoring or purifying fantasies, and compensatory acting out. There are also numerous methods implemented independently or with the help of an object, such as complacency or "manifestations of maternal care" [2].

The techniques for managing your emotions are:

- music;

- physical exercise;

- self-embracement;

- meditation;

- positive thinking;

- emotional freedom technique;

- rational analysis: pros and cons, choice.

In our practice, we often use the "Drawing of emotions and feelings" art therapy exercise [5]. In performing this technique, conditions are created that effectively help the person act the traumatic emotions out and "find his/her own answer."

The purpose and priority objectives are identification of an emotional background, actualized emotions, feelings, and experiences; in a situation of acute stress, prompt assistance, acting out of traumatic experiences, and emotional discharge; "working through" the emotions and feelings, including the suppressed ones; psychoprophylaxis of negative emotional experiences and their manifestations; emotional switch; assistance in the development of spontaneity and reflection, and in manifestation of true feelings; harmonization of the emotional state as a potential for overcoming destructive personality changes and personal growth; the development of creativity.

Materials: sheets of white paper of different format, simple pencils, brushes, watercolors, water bowls.

Tuning stage

Write down on a sheet of paper the emotions, feelings, experiences, and states that you've managed to remember. It is further offered to choose the strongest feeling, experience from the list, which causes an emotional response at the moment.

Stage of individual work (theme development)

Instructions: make an outline drawing of the emotion (feeling, experience, state), chosen for "working through," on an A3 or A4 format sheet of paper with a simple pencil. Do the following to the paper (paying attention to the thoughts and feelings that arise during the work): crumple the sheet of paper with the drawing outlines, lower it into the water for a while, spread it out, lay it on the table, and then paint the image outlined with a simple pencil. Come up with a name and a story that this "picture" could tell. Construct dialogs between the depicted objects or parts of the drawing.

Stage of discussion and reflexive analysis

Place the works in the space of the room, discuss, verbalize emotions and feelings. In the process of work, the image that is being created is transformed, and therefore, its design changes and the hidden meanings are realized.

During the discussion, it is possible to correctly use "questions with prompts" to facilitate the comprehension and transformation of traumatic experiences into the resource ones. It is especially important to create a safe atmosphere of trust, openness, and empathy, so that the provided feedback does not cause traumatic feelings, and is adequately perceived by the person. The therapeutic session is completed by making changes to the created artistic product in accordance with the author's wish. In general, the expected practical result is the transfer of the acquired experience to the everyday interpersonal behavior of the subject outside the therapeutic group.

The main concept of modern Western psychology is selfobservation. For example, when we are angry, we begin to reflect on anger and its cause; we analyze it and thus focus our attention on the feeling rather than on ourselves. It is a thought process that leads to our understanding that anger is bad for us. But if we decide for ourselves that we will never be angry, and we try to restrain anger using our willpower, with no deep internal changes taking place, we simply drive the emotion inside where it acts imperceptibly, and nonetheless more destructively. While Eastern psychology says, "Just realize; there is no point in analyzing and thinking about anger."

So, how do you prevent the development of a state of affect? It would require that you [4]:

- relax, feel all the emotions, evaluate your willingness to act in response to these emotions;

- try to concentrate, see and hear what is happening; ignore unpleasant memories;

- do not associate what is happening at the moment with the negative experience in your life;

- imagine that everything that is happening now is a movie, and feel like an observer in a "bad" situation rather than a participant;

- remember something very positive from your life; 
- do not blame yourself for what has happened;

- the affective reaction is encoded in our brain and occurs in a split second;

- ignore stressful situations;

- resign yourself to a persistent irritant if it cannot be eliminated;

- let your face reflect pleasant emotions more frequently, for example, smile;

- become more active;

- in unpleasant conflict situations, adhere to the opinion of a person who is respected by you or close to you.

Conclusions. So, a person communicates about himself/herself imaginatively in a non-verbal language, learns to understand and analyze his/her emotions, to consciously produce, govern, and to some extent control them. In the process of activity, emotions and fantasies reflecting the traumatic experience of the person and the causes of stress disorder are actualized. The proposed techniques excellently induce free expression of emotions, feelings, and experiences in a symbolic form. The psychologist promotes the development of adaptive resources of the individual, his/her psychological resistance to a traumatic experience, and his/her resistibility in difficult life situations. After all, the nature of the aesthetic reaction, in the words of L. S. Vygotsky, allows you to change the impact of "the affect from the agonizing one to the one that brings pleasure" [1].

\section{ЛИТЕРАТУРА}

1. Выготский Л. С. Психология искусства М.: Искусство, 1982 $573 \mathrm{c}$.

2. Генри Кристал при содействии Джона Х. Кристала. Интеграция и самоисцеление. Аффект, травма и алекситимия. - М.: Институт общегуманитарных исследований, 2006. - 800 с. (Серия: «Теория и практика психоанализа»).

3. Ильин Е. П. Эмоции и чувства. - СПб: Питер, 2001. - 752 с: ил. - (Серия «Мастера психологии»).

4. Кондратенко Н.A [Э. pecypc] http://www.medicalj.ru/ diseases/psychiatrics/1159-sostoyanie-affekta

5. Лебедева Л. Д., Никонорова Ю. В., Тараканова Н. А. Энциклопедия признаков и интерпретаций в проективном рисовании и арт-терапии. - СПб.: Речь, 2006. -336 с.

6. Леонтьев А.Н., Лурия А.Р. Психологические воззрения Л.С. Выготского // Выготского Л.С. Избранные психологические

исследования / Под. ред. А.Н. Леонтьева, А.Р. Лурия. - М.: Изд-во АПН РСФСР, 1956.С.4-36

7. Фортунатов Г. А. Чувства // Общая психология. Учебное пособие. - М., 1970.

8. Holt, R. R. (1976). Drive or wish? A reconsideration of the psychoanalytic theory of motivation. Psychological Issues, Monogr. 9. New York: International Universities Press.

9. Knapp, P. H. (1967). Some riddles or riddance: Relationship between eliminative processes and emotion. Arch. Gen. Psychiat. 586-602.

10. Rapaport, D. (1951). Toward a theory of thinking. In Organization and Pathology of Thought, ed. D. Rapaport. New York: Columbia University Press, 689-729.

11. Schafer, R. (1964). The clinical analysis of affect. J. Amer. Psychoanal. Assn., 275-300.

\section{REFERENCES}

1. Vygotskij, L. (1982), Psihologija iskusstva [Psychology of art], Iskusstvo, Moscow, Russia

2. Krystal, H. along with Krystal, J. H. (2006), Integracija i samoiscelenie. Affekt, travma i aleksitimija [Integration and SelfHealing: Affect, Trauma, Alexithymia], Teorija i praktika psihoanaliza book series, Translated by Starovojtov, V. V., Academy for Humanities and Social Studies, Moscow, Russia.

3. Il'in, E. (2001), Jemocii i chuvstva [Emotions and feelings], Mastera psihologii book series, Piter, St. Petersburg, Russia.

4. Kondratenko, N. A., available at: http://www.medicalj.ru/diseases/psychiatrics/1159-sostoyanieaffekta (accessed September 20, 2017)

5. Lebedeva, L. D., Nikonorova, Ju. V., and Tarakanova, N. A. (2006), Jenciklopedija priznakov i interpretacij v proektivnom ri- sovanii i art-terapii [Encyclopedia of signs and interpretations in projective drawing and art therapy], Rech', St. Petersburg, Russia.

6. Leontiev, A. N. and Luria, A. R. (1956). Psychological views of L. S. Vygotsky. In A. N. Leontiev and A. R. Luria (Eds.), Vygotsky, L. S. Izbrannye psihologicheskie issledovanija [Vygotsky, L. S.Selected psychological studies] (pp. 4-36), Publication of the Academy of Pedagogical Sciences of the Russian Soviet Federated Socialist Republic, Moscow, Russia.

7. Fortunatov, G. A. (1970). Feelings. In G. A. Fortunatov, Obshhaja psihologija [General psychology] (pp. 21-35) teaching aid, Moscow, Russia.

\section{Peculiarities of affects at personal psychic development}

\section{A. D. Tereshchuk}

Abstract. The article is devoted to the study of changes in affects in the course of a person's psychological development. Such changes cannot be reduced to the formation of the mechanisms of defense against strong and unpleasant affects. It is proved that in the course of psychological development, affects have their own trajectory, while the formation of defensive mechanisms is associated, to a large extent, with the defects of this development, because all psychological events, thoughts, and memories have their own affective tint. Each affect has its own history and is associated with some kind of problems in the life of each individual. Some techniques for improving the psychological and emotional state are presented, which contributes to the development of a person's adaptive resources, his/her psychological resistance to a traumatic experience, and his/her resistibility in difficult life situations, as well as for the development of humanely oriented behavior patterns.

Keywords: affects, affective reactions, emotions, behaviors, psychological development, activity.

\section{Особенности аффектов в процессе психического развития личности \\ А. Д. Терещук}

Аннотация. Статья посвящена исследованию изменений аффектов в ходе психического развития личности. Такие изменения нельзя свести к формированию механизмов защиты от сильных и неприятных аффектов. Доказано, что аффекты в ходе психического развития имеют собственную траекторию, тогда как формирование защитных механизмов связано, в значительной мере, с дефектами этого развития. Ведь все психические события, мысли и воспоминание несут свой собственный аффективный окрас. Каждый аффект имеет свою историю и связан с теми или иными проблемами в жизни каждого индивида. Приведены некоторые техники на улучшение психоэмоционального состояния, что способствует развитию адаптивных ресурсов личности, ее психологической устойчивости к психотравмам и сопротивляемости в трудных жизненных ситуациях, выработку гуманноориентированных моделей поведения.

Ключевые слова: аффекты, поведения, аффективные реакции, психическое развития, эмочии, деятельность. 